RAILWAY STATION MEGA-PROJECTS AND THE RE-MAKING OF INNER CITIES IN EUROPE

Gibbons, S. and Machin, S. (2005) Valuing rail access using transport innovations. Journal of Urban Economics, 57(1), pp. 148-169.

Hasselmann, J. (2005) Proteste blieben erfolglos am Zoo hält kein ICE mehr. Der Tagesspiegel, 7 July.

Hops, B. and Kurpjuweit, K. (2007) Hauptbahnhof noch teurer als bekannt. Der Tagesspiegel, 13 January.

Statistisches Amt der Stadt Berlin (1970, 1988) Statistisches Jahrbuch der Stadt Berlin. Berlin. 


\title{
Megaproject as Keyhole Surgery: London Crossrail
}

\author{
MICHAEL HEBBERT
}

\begin{abstract}
London's east-west Crossrail is a civil engineering megaproject designed to produce a minimum of visible change at surface level. The paper explains the origins of Crossrail's 'keyhole surgery' approach, describes the station design process and considers its outcomes in a review of all eight subterranean stations with their twelve surface ticket halls along the central London section between Canary Wharf and Paddington. The strategy is compared and contrasted with Frank Pick's design thinking for London Underground and with the closer precedents of Paris's RER Ligne A. We show how the discreet keyhole concept has to be balanced against the requirements of (a) glazed façades to bring daylight into interior circulation spaces, and (b) design and management of exterior circulation spaces, given the increases in footfall anticipated around each ticket hall when Crossrail opens in 2018. Urban design of station settings remains unfinished business.
\end{abstract}

Construction of London Crossrail began in May 2009 and is scheduled to last 8 years, creating an east-west National Rail line running 118 kilometres though central London between Heathrow Airport and Maidenhead in the Thames Valley, and Kent, Essex and the growth corridor of the Thames estuary (figure 1). Crossrail uses existing trackbeds in the suburbs but dives deep underneath the central area for a 10 kilometre stretch that includes major new station interchanges at Paddington, Bond Street, Tottenham Court Road, Farringdon, Liverpool Street, Whitechapel, Stratford, the Isle of Dogs, Custom House and Woolwich. The ten-coach trains have capacity for 1,500 passengers, double that of Jubilee Line trains, and will achieve peak frequencies of two or three minutes. Carrying 78,000 passengers per hour, Crossrail will boost London's rail transport capacity by 10 per cent (Mayor of London, 2009, p. 113).

With a cost of $£ 15.9$ billion, Europe's largest current contract and the UK's largest investment ever, this is a mega-project by any standard. But it is a moot question how it fits in a special issue on rail stations as prime movers of urban redevelopment. Planning and property factors never figured much in the case for Crossrail (CRL, 2003; 2007; Montague, 2004). In the four sites where it coincides with major development areas - at Paddington, Liverpool Street, Canary Wharf and Stratford - the line is being fitted in as an afterthought. Most of its stations have been designed to minimize redevelopment impacts. So this mega-project earns its place in the 'Railways, Real Estate and Re-Making of Cities' issue of Built Environment as a counter-example, a railway whose stations have been designed as a series of keyhole operations.

\section{Background to Crossrail}

London never had a Hauptbahnhof. Its national rail termini are located in a ring around the central area and passengers walk 


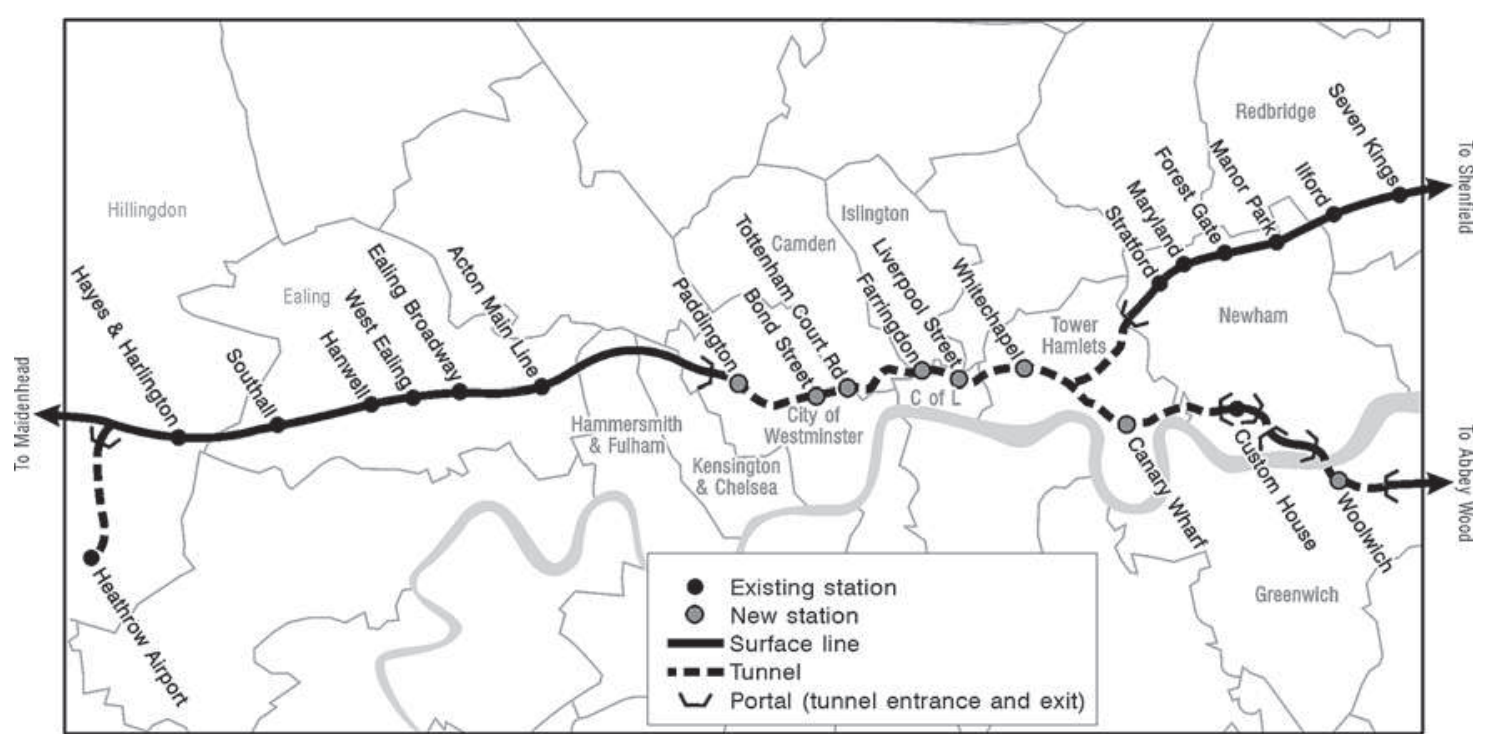

Figure 1. Crossrail - the route in its regional setting. (Source: Courtesy of CLRL)

or transfer to underground, bus or taxi to their final destinations. Plans to extend rail services through the heart of the metropolis have been on drawing boards since at least 1948 and the benefits identified in successive strategies for the London region (Bolden and Harman, 2008). In the 1980s new tracks were laid through the derelict Snow Hill tunnel in the City of London, linking the terminals of King's Cross and Blackfriars and opening the way for Thameslink (1988), the $225 \mathrm{~km}$ north-south connection between Bedford and Brighton via central London and Gatwick Airport. The Central London Rail Study of 1989 highlighted the even greater need for improved rail connection between the west side of London and the emerging employment areas of Docklands and the regenerating east (DoT, 1989). So the government launched the Crossrail project. A first version was rejected by Parliament in 1994 but the concept continued to reappear in spatial strategies for London and the metropolitan region. The London Plan of 2004 stated that an infrastructure linking West End, City and Docklands into a 'virtual unified economic and business core' was essential for London's global business success
(Mayor of London, 2004, p. 115). Steeply rising passenger numbers and overcrowding encouraged the Department for Transport to revive the project in 2003. To promote it, the Strategic Rail Authority and Transport for London formed a partnership under the name of Cross London Rail Links Ltd (CLRL). Thanks to the work done ten years previously CLRL rapidly brought the design to a sufficient level of detail to prepare an Environmental Statement and submit it to Parliament as the London Crossrail Bill in February 2005. As a 'hybrid' bill - legislation of general interest that could significantly affect the interests of specific individuals or organizations - it had a special procedure allowing objectors to represent their interests through petitions for scrutiny by committees of the House of Commons and House of Lords (HoC, 2005). Four hundred and sixtysix petitions were received, many withdrawn after negotiation, 205 heard by the Commons Select Committee and forty-five by the Lords Select Committee. This process of legislative scrutiny lasted three and a half years and resulted in several modifications, including changes in the strategy for tunnelling and spoil removal, and a revised ventilation 
system requiring fewer shafts. The bill received Royal Assent in July 2008.

Through all this time the design team had continued, with government support, to prepare the way for construction. Work was inaugurated at Canary Wharf in May 2009 by Prime Minister Gordon Brown and the Mayor of London, Boris Johnson. By now the financial services sector was in crisis, putting in question the optimistic financialsector growth projections on which Crossrail was based. In a context of deep spending cuts after the 2010 election, rumours abounded that the megaproject would be scaled down or mothballed. The Mayor of London vowed to stage a Stalingrad defence on its behalf (Crerar, 2010). Fortunately its funding model was broadly-based: half the Department for Transport's contribution of $£ 5$ bn had been spent up-front in the design and parliamentary approval process, and the balance would come from Transport for London ( $£ 2.7 \mathrm{bn}$ from fare revenues); Network Rail (£2.3bn); the Mayor and Greater London Authority ( $£ 3.5 b n$ through supplementary business rates and levies on new development); the European Investment Bank (£1bn); and private sector parties, including Heathrow owner BAA, businesses based in the City of London, Canary Wharf Group and Berkeley Homes (£3.5bn). The corporate leadership group London First, headed by Lady Jo Valentine, lobbied strenuously to dispel business doubts (figure 2) and keep the project on track. In July 2010, the Transport Minister Theresa Villiers declared that the government still supported Crossrail as 'high value for money'. It was duly confirmed in the Comprehensive Spending Review of October 2010, and the main station designs were unveiled with a fanfare by Mayor Boris Johnson the following month.

\section{The Design Philosophy}

Decision-making for Crossrail was framed around two basic considerations: on the positive side, the agglomeration benefits of enhanced productivity for the London economy, particularly its financial services cluster; on the negative, the environmental costs of noise, vibration, dust, ground settlement, traffic disruption, and 'impacts on townscape, landscape, visual amenity, heritage and

\section{THE DIRECTORS}
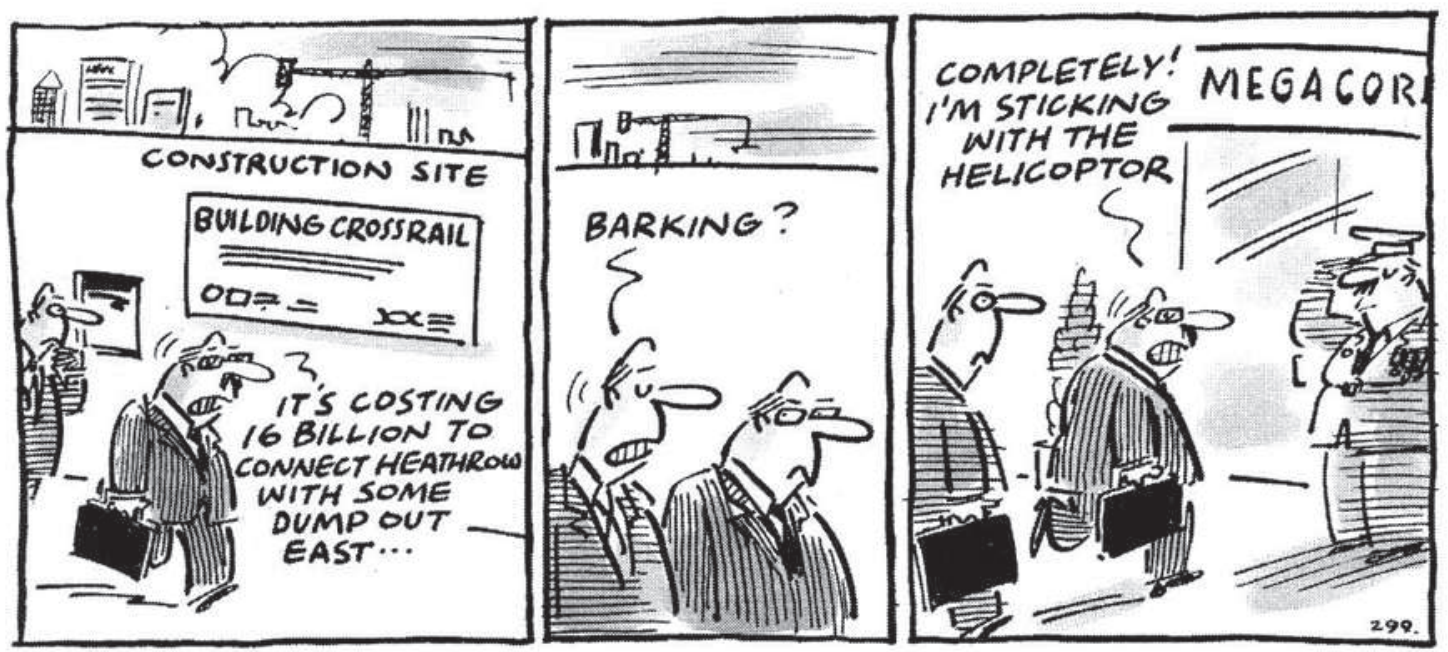

Figure 2. Private Eye, 4 September 2009. (Source: Reproduced by kind permission of Private Eye/ P. Dredge and P. Rigg) 
archaeology' (HMG, 2007). Assessing these impacts for an ancient, complex city such as London was a monumental task: the Crossrail Act documentation included an Environmental Statement running to nine volumes, nine additional ES documents to cover amendments to the scheme, and a further nine Non-Technical Summaries. Thanks to the Hybrid Bill procedure, the project took shape in a calculus which required particular and localized negative effects to be mitigated for the sake of a wide economic good. Demands of local impactmitigation discouraged consideration of new stations as nodes with positive placemaking potential. The tabulation of costs and benefits set out in the UK Government's official Overview of the Case for Crossrail and its Environmental Impacts (HMG, 2007) (table 1) covered the transformative impact of stations on their settings in one word - 'regeneration'. In Amsterdam, Berlin, Rotterdam, Stuttgart

Table 1. Summary of reasons for government's proposal to endorse Crossrail.

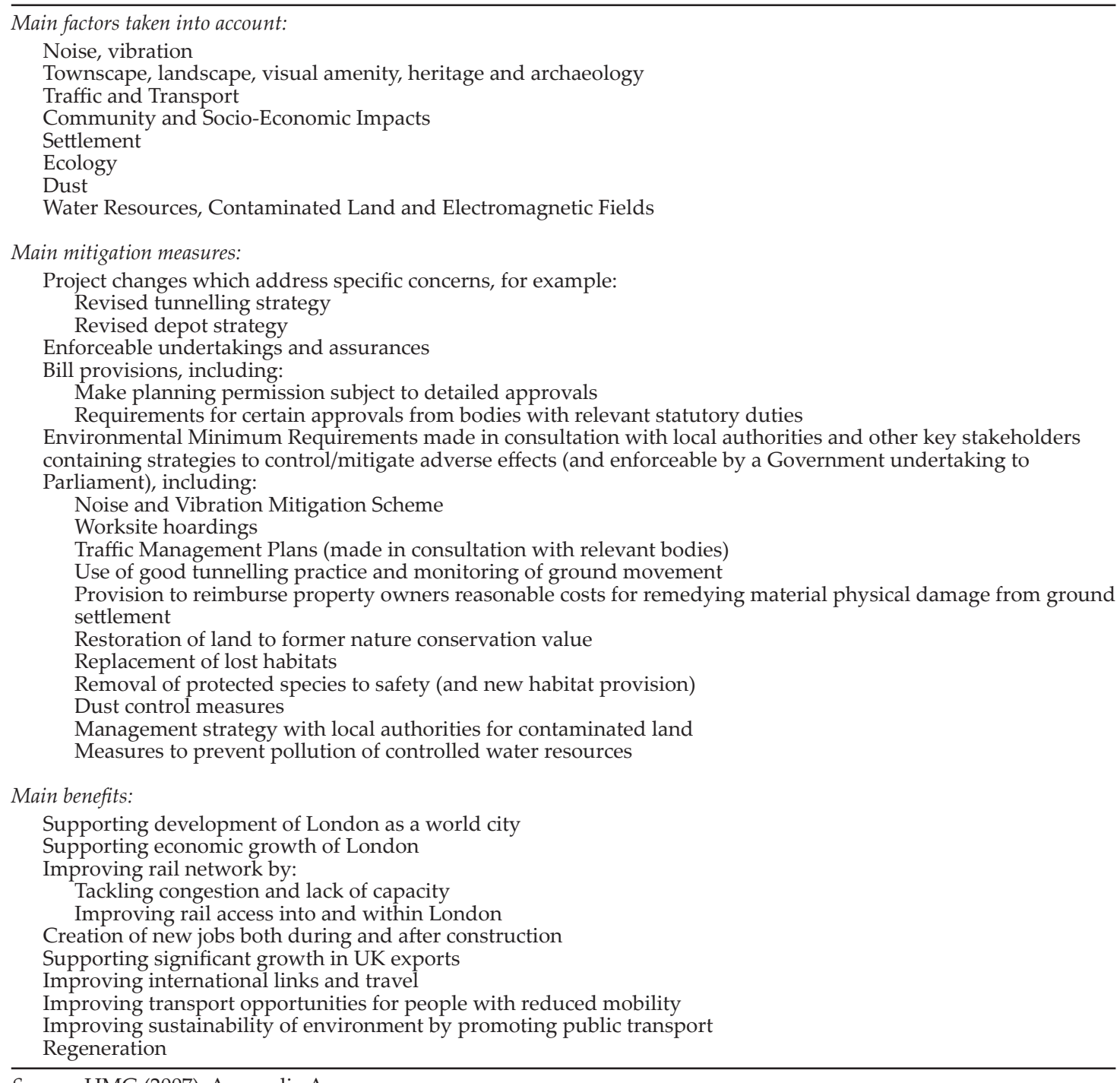

Source: HMG (2007), Appendix A. 
and Zurich, urban design was a paramount consideration, in London not so.

Crossrail's design evolution has been closely followed in the architectural press. It was feared design quality would be treated as an optional add-on to the engineering realm of tunnels, ventilation shafts, escalators and lifts. There was anxiety when all the station architectural contracts were re-advertised in 2008 and consternation when the incoming Crossrail chairman, Terry Morgan, commented that 'as an engineer' he was concerned about the balance between visual aspects and functionality: 'We have to decide on how far we take the idea of a design legacy - that's where the costs go very quickly if you're not careful' (Building Design, 2009a, 2009b). The generally low-cost materials and utilitarian layouts of stations on London's new Overground line were held up as ominous precedents for Crossrail (Hatherley, 2010).

The implicit reference point in all such discussions was London's previous major rail project, the Jubilee Line Extension (JLE). This ran $£ 2$ bn over budget but created wonderful underground stations that made a clean break with the grudging functionalism that for too long dominated UK railway design (Haywood, 2009). Many of the JLE team had transferred to London in 1990 directly from the Hong Kong Mass Transit Authority, where they pioneered the cut-and-cover method of station construction. The 'Hong Kong Box' allowed the design director Roland Romano Poaletti to involve architects in underground as well as surface spaces, with spectacular consequences. He applied the approach to JLE, encouraging creativity within a restricted palette of materials and a clearly articulated visual philosophy which Andrew Saint (2000) links to London's need to banish claustrophobia and make a new start after the catastrophic Kings Cross underground escalator fire of 1987:

If you bore a tunnel out for an underground station you are still in darkness. But if you scoop out a great box from above you can let the light flood down in. That is what has been done all along the JLE. You will have to put the lid back on top of your box ... but it still gives you a tract of space below ... to play with: and if you manipulate the healing daylight you can get it to bounce off roofs and walls and pour deep into the bowels of the earth, if never to the platforms themselves.

Crossrail architectural guidelines (table 2) showed the influence of this Hong Kong/ JLE design vision, encouraging designers to introduce natural light into underground spaces wherever possible.

Another important precedent was the design of stations for the five lines of the Parisian Réseau Express Régional (RER). There is an uncanny similarity between the length, station numbers, tunnel distances and passenger capacities of Crossrail and its forty-year predecessor RER Ligne A, which opened in 1977 (Boagey and Genain, 2009). The hugely successful RER network runs at two minute frequencies and carries a million passengers a day. The high volumes are achieved through long station platforms with ample space for passengers to be loaded and unloaded. Crossrail's designs reflect the same philosophy, with platforms 240 metres long and spacious underground concourses often linked to widely separated ticket halls at either end. In the words of Guardian architecture correspondent, 'whether in the booking offices, concourses or platforms ... every effort appears to have been made to shape generous and free-flowing spaces designed to cope with future demand. The lessons of the high-quality Jubilee line extension between Westminster and Stratford have been learned. Flow is all' (Glancey, 2010).

So Crossrail station design combines voluminous daylit interior spaces where the emphasis is on flow, with a keyhole surgery approach to urbanism where the emphasis is on minimizing disruption to the exterior fabric of streets and blocks: tightly located pavement entrances opening into deceptively spacious ticket halls. There are echoes here 
Table 2. Crossrail basic design principles.

1. Crossrail must be a world class transport system

2. The design should aspire to be lasting;

3. It should integrate with and be respectful of the fabric of the city;

4. The project should encourage the development of public realm initiatives to maximize public benefit;

5. Alterations to historic buildings and townscape should be sympathetic;

6. Passenger experience should be comfortable, pleasant and safe;

7. Where possible natural light should be introduced into underground spaces;

8. Ticket offices should be at ground level, visible, transparent and two storeys high if possible;

9. Way finding should be intuitive;

10. Design should be brand neutral;

11. Materials should be self finished, robust and of good quality;

12. Good sightlines should be encouraged to assist in reducing crime;

13. Lighting should be of a high standard to encourage wellbeing and safety;

14. Spaces should aid free movement and be free of visual clutter and obstructions;

15. New stations will provide step-free access from street to Crossrail platform.

Source: Hebbert (2006).

of the typology that Frank Pick developed in partnership with the architect Charles Holden for London Underground stations of the interwar years: a 'hole in the wall' entrance into a generous and clutter-free ticket hall with daylight illumination (Barman, 1979, p. 138). But how can such a keyhole typology be applied to the much larger main-line stations now under construction across London? To answer this question we look first at the individual sites along the underground section of the Crossrail line from west to east, and then at the general issues they pose.

\section{The Stations Take Shape}

Long before tunnel-boring machines began cutting Crossrail's path through the clay beds, Londoners had become accustomed to picking their way round the blue hoardings of railway construction sites. The elaborate preparatory work included rerouting water mains, sewers and other infrastructure, deep piling to support stations and subsequent overhead development, and the drilling of 'compensation grouting' shafts for injecting cement into the substrate to protect the fabric of streets and buildings from the ground settlement effects of tunnelling and train vibration. Crossrail webpages began to fill with construction updates and distanceto-the-moon statistics, time-lapse videos of buildings being demolished and holes dug, and renderings and virtual reality animations of gleaming stations to be.

The first of the tunnelled rail stations is Paddington, a six-way interchange with main and suburban rail services, and London Underground's Circle, District, Metropolitan \& City, and Bakerloo lines. Crossrail runs alongside the existing terminus tracks, effectively creating a subterranean parallel westward enlargement of the main Paddington concourse. Its new platforms are expected to generate 27,700 passenger arrivals and 30,500 departures in the morning peak period (7 am to $10 \mathrm{am}$ ). The huge increase of capacity has to be achieved within tight 
conservation constraints - the station is set in the Bayswater Conservation Area, and its buildings are all listed either Grade 1 or Grade 2. The solution has been to place the Crossrail station out of sight in a giant cut and cover excavation underneath Eastbourne Terrace, reinstating the road 3 metres below its present level, with a glazed 'light-spine' to let light into the cavity beneath. The insertion leaves the historic structures untouched apart from the loss of the glazed canopy over the taxi rank, which has to be shifted to the far side of the station.

The Crossrail tunnels swing eastwards under Bayswater Road and Hyde Park to the next station, Bond Street, gateway to the retail core of Oxford Street. Rumours in the spring of 2010 that the stop might be cut to save costs prompted intensive top-level lobbying from the bosses of Marks and Spencer, Debenhams and Selfridges. The existing Underground Station already handles 125,000 passengers daily and Crossrail will boost the flow to 220,000. Its station has to be fitted into the fine-grained urban landscape of the Grosvenor Estate, where top-end fashion boutiques and antique shops mingle in a varied tissue of land uses, architectural styles and building types under the strict conservation régime of Westminster City
Council. The solution (figure 3 ) is to excavate two widely separated stations, one at the intersection of Davies Street and Weighhouse Street linked to the Bond Street station on the Jubilee and Central tube lines, the other 350 metres to the east, replacing a nondescript 1960s office block at 18-19 Hanover Square, oriented towards Oxford Circus and Regent Street, each ticket hall being designed to support new development in due course. Below ground the western station is being integrated with an upgrade of the existing Bond Street Underground station, which may in turn be combined with a redevelopment of the West One shopping centre.

At Tottenham Court Road (figure 4) the narrow characterful streets of the Soho Conservation Area have presented an even greater challenge for keyhole surgery. The western ticket hall, opening directly onto the pavement of Oxford Street, displaced two historic street-blocks between Great Chapel Street and Dean Street - a bird's-eye video of their demolition can be seen on the Crossrail website. The flank walls of the new station may evoke the vertical rhythms of the eighteenth-century plots but not their vibrant street-life. Crossrail's eastern escalators lead up to Tottenham Court Road, on the boundary between the City of Westminster

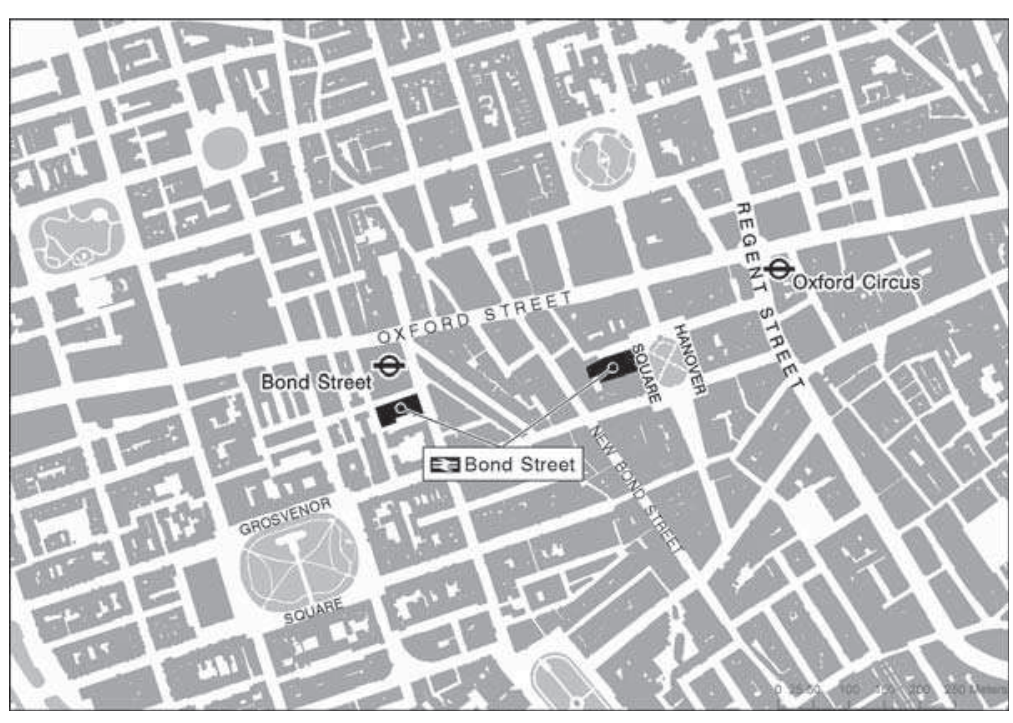

Figure 3. Bond Street stations. (Source: Map by Graham Bowden, SED) 
and the London Borough of Camden, a long-term problem spot where London's 'borough effect' shows up in passenger overcrowding, pedestrian bottlenecks and a lacklustre environment (Hebbert, 1991). The Mayor's London Plan (2011) designates the 19 hectares around Centre Point as a node for new development with capacity for 5,000 new jobs, and associated public realm enhancement across borough boundaries. Crossrail provides the key to unlock this potential. An integrated concourse with London Underground is being constructed beneath Charing Cross Road, and a new public plaza replaces the traffic-dominated intersection at the foot of the listed office block, Centre Point. Only Docomomo enthusiasts noticed the demolition of the original 1960s water feature in the gyratory (Arnold, 2009), but there was general dismay at the loss of the Astoria Theatre across the road. The closure and disappearance of this music venue in 2009 was the first public indication that Crossrail was for real.

The next Crossrail stop is Farringdon, 2 kilometres to the east. This too is an 'area for intensification' according to the London Plan (Mayor of London, 2004, 2011), but it is a peripheral location from the perspectives of the City Corporation and the London Borough of Islington, whose boundaries it straddles. The present station on the Circle and Metropolitan lines is an elegant example of the earliest underground railway architecture (1865), tucked into Cowcross Street between the Hatton Garden jewellery district, Smithfield meat market and the historic workshop district of Clerkenwell, now a gentrified quarter of small offices, restaurants and night clubs. Farringdon Station used to be a backwater but its importance has grown since it became an interchange with National Rail's north-south Thameslink. Crossrail will take the station to another order of magnitude, making Farringdon an equivalent to Châtelet-Les Halles where Lignes A and B intersect at the heart of the Parisian RER. The contrast could hardly be greater. The urban setting of the Châtelet-Les Halles pôle d'échange was totally remodelled in the 1970s and President Sarkozy has it in his sights for a fresh grand projet of urban renewal, whereas Farringdon's design (figure 5) is a keyhole solution of twin ticket halls inserted into single sites to either end of the platforms. The western ticket hall is being excavated on the site of a 1960s office block on the corner of Cowcross Street and Farringdon Road. Though it provides an integrated concourse for Crossrail and Thameslink, passengers will need to come outside and walk across the street to take
Figure 4. Tottenham Court Road stations. (Source: 3D Courtesy of CLRL)

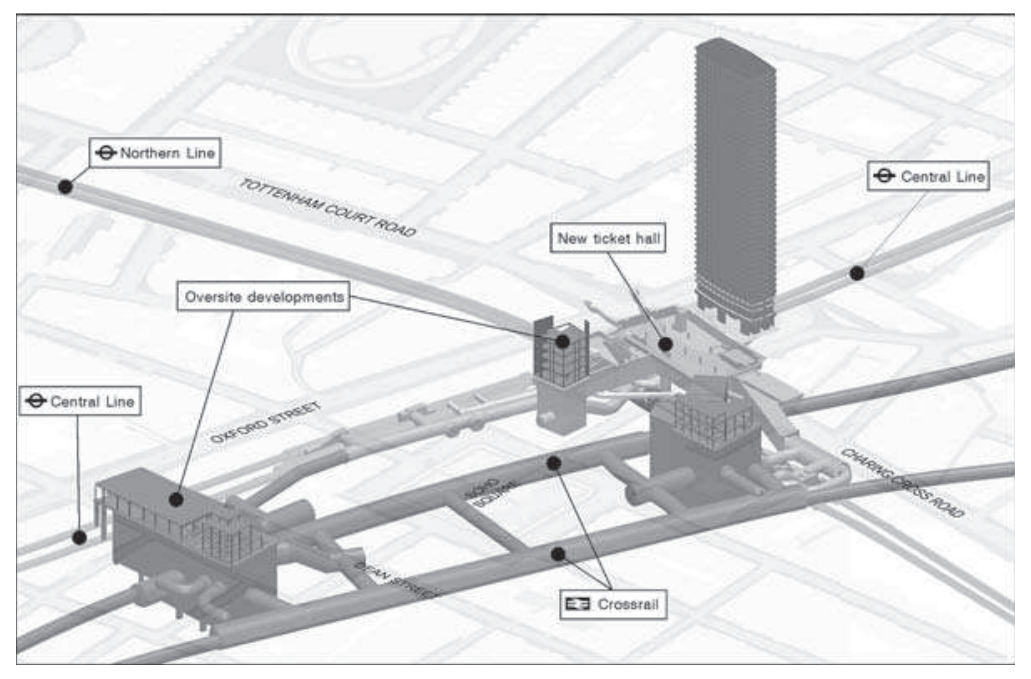

BUILT ENVIRONMENT VOL 37 NO 8 
the Underground. Design reviewers were critical of its 'mediocre' appearance and disconnection from its setting:

Whilst we accept the decision to submit separate applications for the station and public realm improvements, it would be best practice for their designs to be developed in parallel. This would allow for an iterative design process, allowing streetscape ideas to inform the station design and vice versa. We would also have found it useful to have information on public realm improvements as part of the background information for our review of the station. (CABE, 2009)

Here as elsewhere, the design process has focused more on the operational premises than the surroundings which huge passenger flows - 750,000 per day in the case of Châtelet-Les Halles - will inevitably transform.

Farringdon's eastern ticket hall has slotted a modern station hall into another long, narrow street block. Its site in Lindsey Street is tightly hedged by conservation constraints, lying between two surviving mediaeval foundations - St Batholomew's Hospital to the south and the Charterhouse to the north. Immediately across the street are the Grade II listed buildings of Smithfield Meat Market. The surrounding streets have a fine-grained townscape, with many historic properties and a lively mix of uses. Parisian RER precedents might have suggested a compact rat-hole entrance in this setting, but the solution is again a double-height concourse in a long, horizontal glazed box, with a new building overhead.

Crossrail's busiest station, Liverpool Street, (figure 6) follows just a kilometre to the east. Confusingly, its western ticket hall is connected into the existing London Underground station at Moorgate, a good ten minutes' walk from Liverpool Street proper. Its design follows the Crossrail template, taking out yet another narrow north-south street block to create a high-ceilinged concourse with natural daylight, the ticket hall floor being set below street level but visible through the glass walls from the pavements above, with station access via a wide glazed passageway linking Moorgate and Moorfields. Some 500 metres away by tunnel and escalator, the eastern ticket hall connects Crossrail into Liverpool Street underground station and the historic railway terminus which is London's gateway to the east of England. A vent shaft, maintenance access and emergency escape stairs are being inserted, keyhole-fashion, into a narrow site with a frontage on Blomfield Street and rear access from the small cul-de-sac of Broad

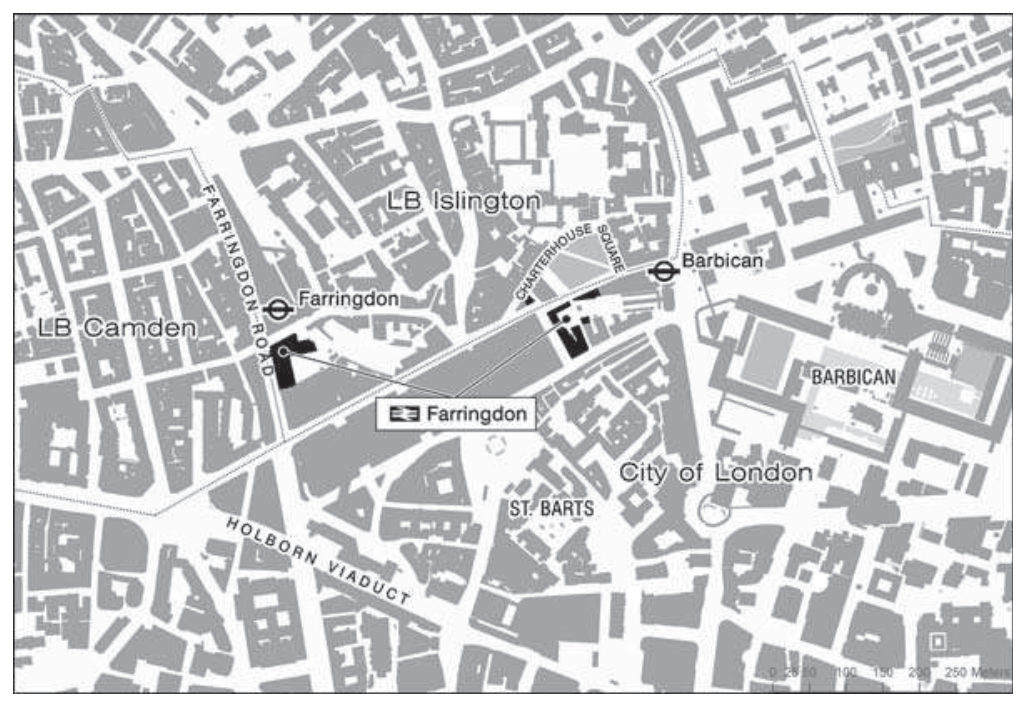

Figure 5. Farringdon stations. (Source: Map by Graham Bowden, SED) 
Figure 6. Liverpool Street stations. (Source: 3D Courtesy of CLRL)

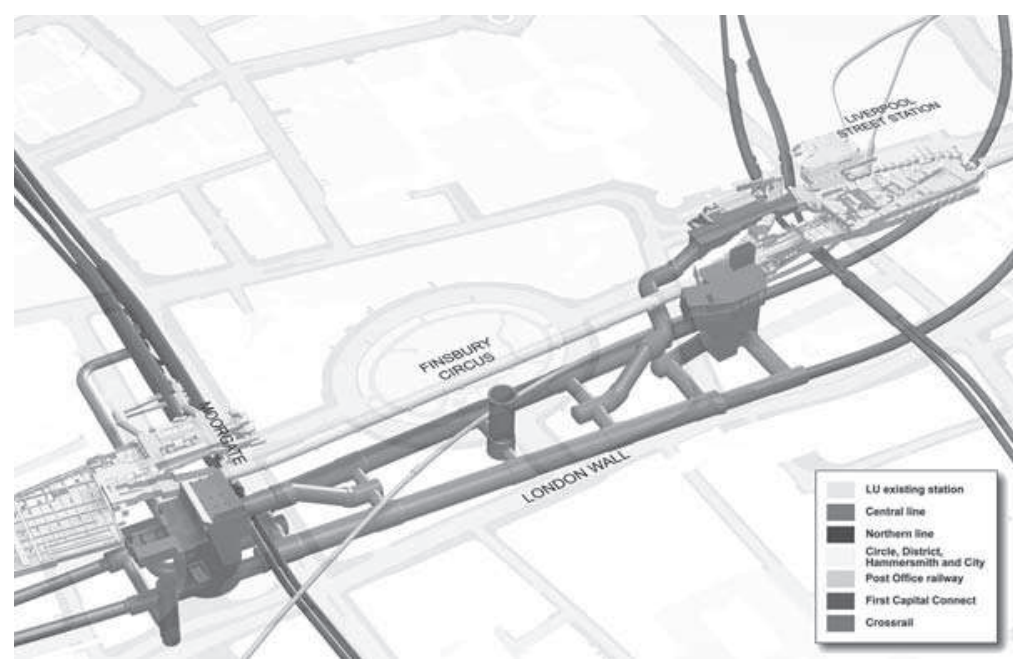

Street Avenue. Venting equipment is being cantilevered over the open cutting of the Metropolitan Line. Construction of these projects is highly disruptive for this corner of London, with large areas of pavement hoarded off and the beautiful park of Finsbury Circus transformed into a multistorey engineering encampment. The point is that 10 years from now the townscape will be totally reinstated, albeit subtly redesigned to remove clutter and enhance the environment for the even higher volumes of people walking, sitting, milling about or just chilling out by the entrance to Liverpool Street Station (Dales, 2011).

The next stop is Whitechapel in the heart of the East End. This station connects Crossrail to south-east and north London via the expanded and modernized Overground line, and also provides another interchange with the District and Hammersmith Lines. From an urban design viewpoint it is a peculiarly difficult insertion. The existing Whitechapel Station slots into the linear morphology of Whitechapel Road, where small shops and a large street market coexist with dense pedestrian and vehicle flows. Across the street the Grade II listed frontage of the Royal London Hospital masks a huge medical campus. Crossrail originally proposed to set a new station entrance and concourse behind the street façade on the north side, facing towards quiet residential streets and away from the major destination of the hospital. That solution minimized short-term

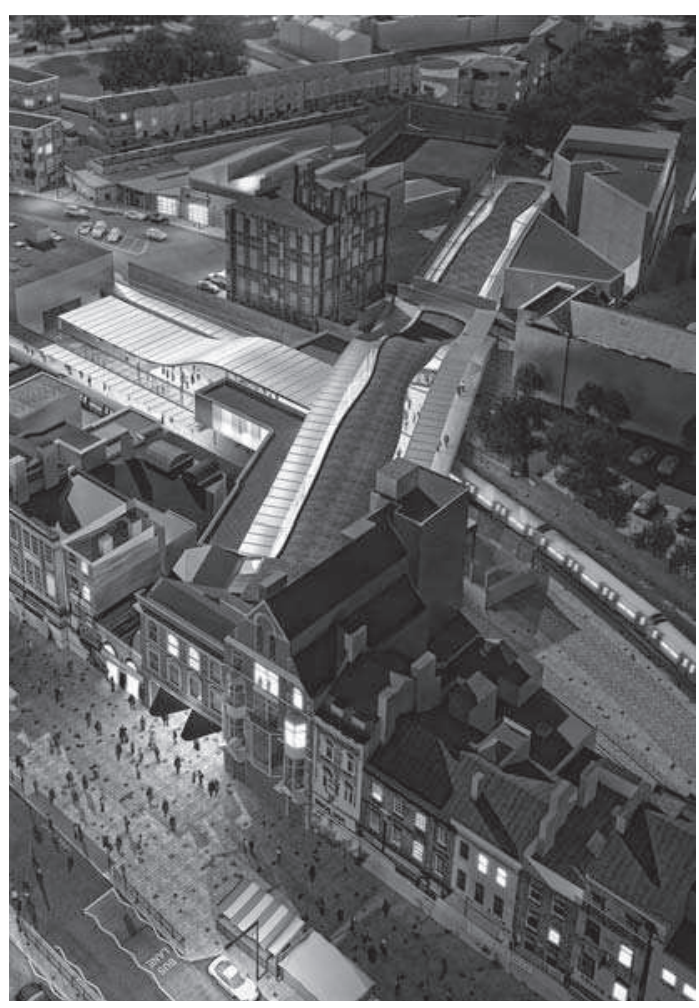

Figure 7. Whitechapel station bird's-eye view. (Source: Courtesy of CLRL) 
disruption but made no sense in terms of urbanism. In 2010 it was amended to provide an appropriately scaled entrance through the existing street façade into the bustle of the main thoroughfare (figure 7).

Beyond Whitechapel the line splits to serve the two sides of the Thames estuary. The first stop on the Essex-bound section is Stratford Regional Station, already enlarged and transformed to accommodate the arrivals of the Jubilee Line, London Overground, a Docklands Light Railway extension from ExCel, the 2012 Olympics, and the gigantic Westfield shopping mall (Pasquale and McNulty, 2011). No keyhole surgery here, the interchange is ready-made. We find a very different situation at the first stop on the Kent-bound line, the huge financial and business district of Canary Wharf. The Docklands high-rise cluster has expanded steadily from a zero base-line since 1985, with employment projected to rise to 200,000 and enough shopping provision to qualify it as one of London's 'major' town centres (GLA, 2011). Once derided for having none, Canary Wharf is acquiring an excellent rail infrastructure through a process best described as disjointed incrementalism. Its Crossrail station (figure 8) is being constructed by the Canary Wharf Group on a site reclaimed from the waters of the West India Dock. Norman Foster's glorious Jubilee

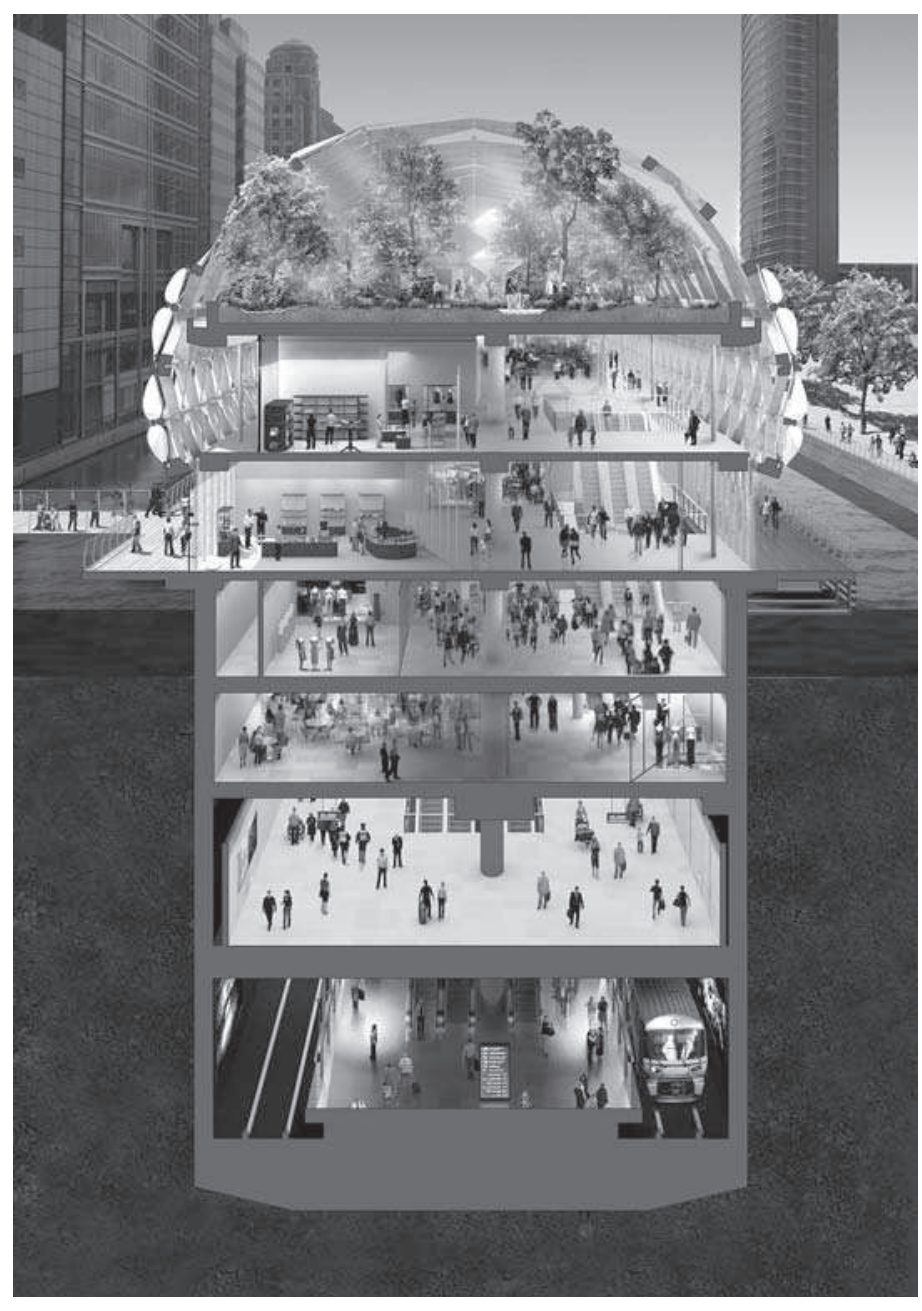

Figure 8. Canary Wharf station crosssection. (Source: Courtesy of CLRL) 
Line Underground station lies 250 metres to the south and the elevated Docklands Light Railway station a similar distance to the west. The three points of the triangle connect through the streets and underground shopping malls of the Wharf, spreading pedestrian footfall and transforming the entire Canary Wharf Estate into a transport interchange. No rational design process would have arrived at this solution but the place is destination enough for the inconvenience to pass unnoticed, at least by the able-bodied.

\section{Conclusion}

It is still difficult to get Crossrail into proportion. On the one hand, the keyholesurgery design to minimize intrusion on the London townscape is masked by construction phase impacts as buildings are demolished and familiar routes blocked by blue project hoardings that commandeer half the carriageway (figure 9). In November 2010 the Guardian newspaper reported 'unexpected views of central London ... as if someone has taken a giant tin opener to the city's skyline' (Glancey, 2010). But the impact of the clearances and the work-sites is deceptive when the hoardings eventually come down original building-lines will be reinstated and the original three-dimensional street pattern restored.

On the other hand, the strategic impact of the new line is almost too big to grasp. It carries to a new order of magnitude the rebalancing of east and west London through high-specification public transport, a process started by the DLR and strongly reinforced by the Jubilee Line (Hickman and Hall, 2008). The success of the project depends on more than efficient passenger flow. Each station has to perform in terms of 'place' as well as 'node' and balancing these factors is no easier in keyhole surgery that in the open chest operations analysed by Bertolini and Spit (1998) and by fellowcontributors to the present issue. The Crossrail stations do not employ architectural assertion. Slotting where they can into the city's permeable irregular street grid, they maintain London's indigenous tradition of avoiding set-piece design and emphasizing the different characters of localities. The insertion of the new stations into the local public realm is being negotiated through a
Figure 9. Pedestrian deviation at St Giles's Circus, Autumn 2010. (Source: author's photograph)

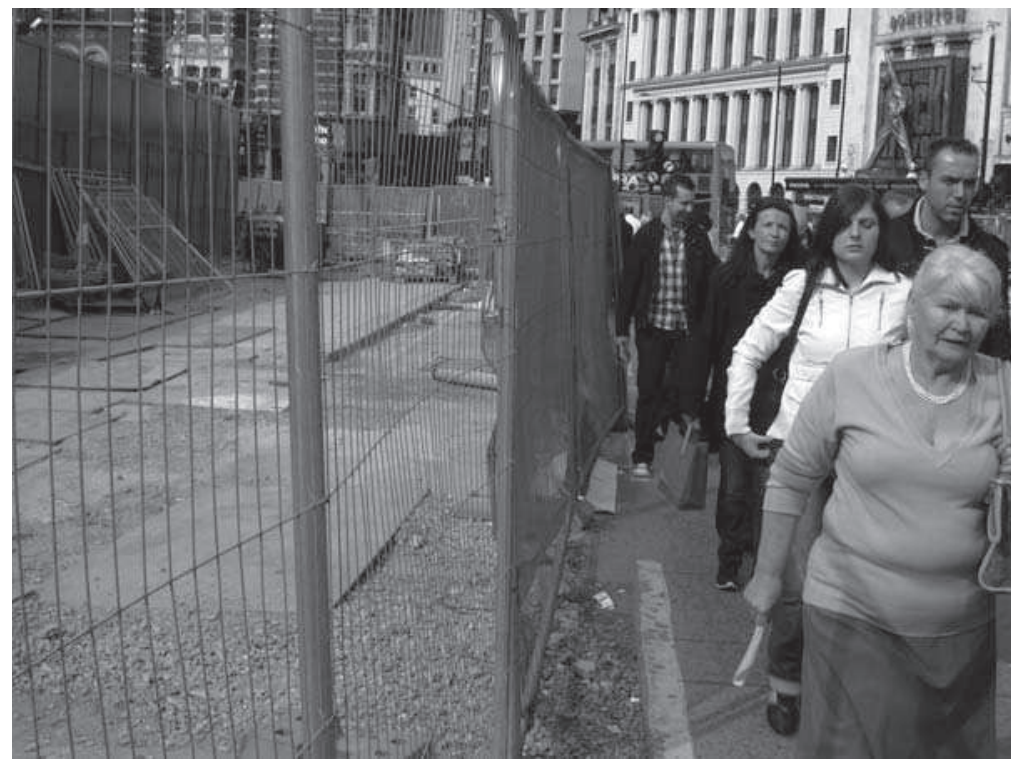

BUILT ENVIRONMENT VOL 37 NO 8 
variety of mechanisms. Some councils have set up local policy frameworks, with the City of Westminster in the lead. Crossrail and local stakeholders came together for design review meetings with a small independent panel to review each site and setting. This was followed in 2008 by a dedicated review group of eight architects, engineers and urbanists operating within the Commission for Architecture and the Built Environment (CABE) chaired by Les Sparks OBE (Hebbert, 2006; CABE, 2008, 2009). In 2010 a 'memorandum of understanding for the urban realm and transport interchange at Crossrail stations' was signed by all the local authorities and transport stakeholders along the line, setting out joint procedures and principles, if not funding mechanisms, for integrated planning and implementation of the new station settings (CRL, 2010).

Transport for London's best practice guidance is being used as the basis for interchanges and the adjacent public realm. The Underground network sets good historic precedents for keyhole design. Frank Pick's Underground stations minimized surface intrusion yet were never unobtrusive like their New York counterparts. Supremely aware of the contribution of station design to the brand identity of rail travel (Ross, 2000), Pick made hole-in-the-wall and streetcorner entrances visible and legible: red white and blue roundels, cream terracotta tiling, canopies with blue fascias, and Edward Johnston's sans-serif lettering made each station a local landmark while revealing how the interconnected network opened up the entirety of London to the travelling public (Barman, 1979). It is not yet known how Crossrail will be branded by its future private operator, except presumably for the signage of contra-facing arrows that will indicate a railway station. Its architecture has been kept deliberately clean, bright and neutral. It will be for the Mayor of London to ensure that brand reticence is not overdone, and that the finished stations have a visual personality to express the importance of their contribution to London's twenty-first century transport infrastructure.

\section{REFERENCES}

Arnold, D. (2009) Conservationists fear the loss of Modernist habitat. The Times, 12 December, p. 117.

Barman, C. (1979) The Man Who Built London Transport - A Biography of Frank Pick Newton Abbot: David \& Charles.

Bertolini, L. and Spit, T. (1998) Cities on Rails: The Redevelopment of Railway Station Areas. London: E \& FN Spon.

Boagley, A. and Genain, M. (2009) London's crosscity line follows the RER model. Railway Gazette International, 165(3), pp. 62-66.

Bolden, T. and Harman, R. (2008) Railway and spatial strategies in the South-East: can coordination and delivery be achieved? Planning Practice and Research, 23(3), pp. 303-322.

Building Design (2009a) Anger as Crossrail chief questions value of design. Building Design, 26 June, p. 3.

Building Design (2009b) Debate: does Crossrail have low design aspirations? Building Design 3 July, pp. 1ff.

CABE (2008) CABE to Review Designs for Crossrail Stations. Press release 19 November 2008. Available at http://webarchive.national archives.gov.uk/20110118095356/http:/www. cabe.org.uk/news/crossrail-station-designreview. Accessed 30 January 2012.

CABE (2009) Farringdon Station Redevelopment (Design review, Crossrail Panel, 24 August 2009, Planning reference P091441). Available at http://webarchive.nationalarchives.gov.uk/ 20110118095356/http:/www.cabe.org.uk/ design-review/crossrail/farringdon-stationredevelopment. Accessed 30 January 2012.

CRL (2003) The Crossrail Business Case London: Cross London Rail Links Ltd. Available at http:// www.crossrail.co.uk/the-railway/crossrailwider-economic-benefits. Accessed 27 July 2010.

CRL (2007) The Economic Benefits of Crossrail London: Colin Buchanan \& Volterra Consulting for Cross London Rail Links Ltd. Available at http://www.crossrail.co.uk/the-railway/cross rail-wider-economic-benefits. Accessed 27 July 2010.

CRL (2010) Memorandum of Understanding for the Urban Realm and Transport Interchange at Crossrail Stations London: Crossrail Ltd. 